\title{
GADAI DALAM PERSPEKTIF KUHPERDATA DAN HUKUM ISLAM
}

\author{
Hanna Masawayh Qatrunnada
}

\author{
Lailatul Choiriyah
}

\author{
Nurul Fitriani \\ UIN Sunan Ampel Surabaya \\ nf4.nurulfitriani@gmail.com
}

\begin{abstract}
This article discusses the law of pawn in terms of the Civil Code and Islamic law. This article is the result of a literature study and is qualitative. Data about pawning is collected through books, journals, and the internet. After the data was collected, it was classified and analyzed descriptively. The results of the discussion concluded that pawning in the Civil Code is regulated in Book II Chapter 20, Article 1150 to Article 1161, while in Islamic law it is included in the discussion of muamalah fiqh. In terms of the Civil Code and Islamic law, they have the same thing that the pawn is collateral for goods because of the existence of accounts payable, and both allow pawning law. The existence of a pawning contract has implications for legal consequences. The Civil Code regulates these provisions in its articles. Islamic law allows pawning based on the arguments of the Koran, Sunnah, and ijma'. Pawn contains benefits, namely to help someone who is experiencing difficulties in their daily activities. The pawn (ar-Rahn) has certain pillars and conditions that must be fulfilled so that the pawn can be implemented based on goodness and benefit for both parties carrying out the transaction. If the pillars and conditions of the mortgage are not fulfilled or violate the terms and conditions in Islam and the elements of benefit, the law is declared null and void.
\end{abstract}

Keywords: Pawn, Civil Code, Islamic law. Abstrak: Artikel ini membahas tentang hukum gadai ditinjau dari KUHPerdata dan
hukum Islam. Artikel ini merupakan hasil dari studi kepustakaan dan bersifat
kualitatif. Data tetang gadai dikumpulkan melalui buku, jurnal dan internet. Setelah
terkumpul data diklasifikasikan dan dianalisis secara deskriptif. Hasil pembahasan
menyimpulkan bahwa gadai dalam KUHPerdata diatur dalam Buku II Bab 20 Pasal
1150 sampai dengan Pasal 1161 KUHPerdata sedangkan dalam hukum Islam ia
termasuk di dalam pembahasan fikih muamalah. Secara pengertian KUHPerdata dan
hukum Islam memiliki kesamaan bahwa gadai merupakan jaminan atas barang
karena adanya hutang piutang, dan keduanya membolehkan hukum gadai. Dengan
adanya akad gadai maka berimplikasi pada akibat hukum. KUHPerdata mengatur
ketentuan-ketentuan tersebut dalam pasal-pasalnya. Hukum Islam memperbolehkan
gadai didasarkan pada dalil al-Quran, Sunnah, dan ijma'. Gadai mengandung
kemaslahatan yaitu untuk membantu seseorang yang sedang mengalami kesulitan

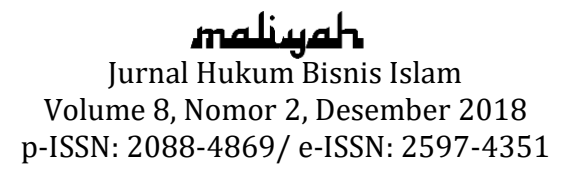


dalam aktifitas kesehariannya. Gadai (ar-rahn) memiliki rukun dan syarat tertentu yang harus terpenuhi agar gadai dapat dilaksanakan berdasarkan kebaikan dan kemaslahatan bagi kedua belah pihak yang melaksanakan transaksi tersebut. Jika rukun dan syarat gadai tidak terpenuhi atau melanggar ketentuan syarat dalam Islam dan unsur kemaslahatan maka hukumnya dinyatakan batal.

Kata Kunci: Gadai, KUHPerdata, hukum Islam.

\section{Pendahuluan}

Islam adalah agama yang memberikan kemudahan dan kemaslahatan bagi penganutnya, ${ }^{1}$ termasuk dalam hal ekonomi. Ekonomi Islam identik dengan prinsip syariah. Syariah merupakan ajaran Islam tentang hukum Islam atau peraturan yang harus dilaksanakan dan/ atau ditinggalkan oleh manusia. Salah satu jasa dalam keuangan dengan ekonomi Islam adalah gadai syariah (al-rahn). ${ }^{2}$ Gadai syariah yang dikenal dengan rahn (mortgage) adalah pelimpahan kekuasaan oleh suatu pihak kepada pihak lain (bank) dalam hal-hal yang boleh diwakilkan. Atas jasanya, maka penerima kekuasaan dapat meminta imbalan tertentu dari pemberi amanah. ${ }^{3}$

Di Indonesia terdapat beberapa peraturan yang menjadi landasan praktik gadai, diantaranya KUHPerdata dan hukum Islam. Berdasarkan hal tersebut penulis tertari membahas hukum gadai dalam perspektif KUHPerdata dan hukum Islam. Metode yang digunakan dalam penulisan ini adalah studi kepustakaan dan kualitatif. Data dikumpulkan melalui buku, jurnal dan internet yang ketika sudah terkumpul maka dianalisis secara deskriptif.

1 Mahmud Arif, "Islam, Kearifan Lokal Dan Kontekstualisasi Pendidikan: Kelenturan, Signifikansi, Dan Implikasi Edukatifnya," Al-Tahrir: Jurnal Pemikiran Islam 15, no. 1 (2015), 70.

${ }^{2}$ Ar-Rahn, adalah suatu akad pada transaksi perbankan syariah, yang merupakan akad gadai yang sesuai dengan syariah. Adi Susilo Jahja, "Analisis Perbandingan Kinerja Keuangan Perbankan Syariah Dengan Perbankan Konvensional," Epistemé: Jurnal Pengembangan Ilmu Keislaman 7, no. 2 (2012), 349.

3 H. B. Syafuri, "Aktivitas Gadai Syariah Dan Implikasinya Terhadap Produktivitas Masyarakat Di Provinsi Banten,” Al-Adalah 12, no. 2 (2014), 437. 


\section{Konsep Gadai dalam KUH Perdata}

Gadai (pand) merupakan salah satu macam kegiatan ekonomi yang dimaksudkan untuk mempermudah masyarakat luas untuk memenuhi salah satu kebutuhan hidupnya yang dirasa sangat mendesak, tanpa harus takut untuk menjual harta bendanya.

Gadai ini diatur dalam Buku II Bab 20 Pasal 1150 sampai dengan Pasal 1161 KUHPerdata. Menurut Pasal 1150 KUHPerdata pengertian dari gadai adalah:

"Suatu hak yang diperoleh seorang berpiutang atas suatu barang bergerak, yang diserahkan kepadanya oleh seorang berutang atau oleh orang lain atas namanya, dan yang memberikan kekuasan kepada si berpiutang itu untuk mengambil pelunasan dari barang tersebut secara didahulukan daripada orang-orang berpiutang lainnya, dengan kekecualian biaya untuk melelang barang tersebut dan biaya yang telah dikeluarkan untuk menyelamatkannya setelah barang itu digadaikan, biayabiaya mana harus didahulukan". ${ }^{4}$

Dari definisi tentang gadai di atas diketahui bahwa terdapat 4 unsur pokok gadai, yaitu: Pertama, gadai lahir karena adanya perjanjian penyerahan kekuasaan atas barang gadai kepada kreditor pemegang gadai. Kedua, penyerahan itu dapat dilakukan oleh debitor atau orang lain atas nama debitor. Ketiga, barang yang menjadi obyek gadai hanya barang bergerak. Sedangkan yang keempat kreditor pemegang gadai berhak untuk mengambil pelunasan dari barang gadai lebih dahulu daripada kreditor-kreditor lainnya. ${ }^{5}$

Sifat-sifat gadai adalah:

1. Gadai adalah hak kebendaan. ${ }^{6}$ Maksudnya adalah hak gadai bukanlah hak untuk menikmati suatu benda seperti hak

\footnotetext{
4 "Buku II Bab 20 Pasal 1150 Sampai Dengan Pasal 1161 KUHPerdata," n.d.

${ }^{5}$ Kitab Undang-Undang Hukum Perdata (Rhedbook Publisher, 2008), 265.

${ }^{6}$ yang bersifat memberi jaminan yang mempunyai sifat-sifat kebendaan yang pada umumnya yang senantiasa melekat atau mengikuti bendanya (droit de suite) dan akan tetap ada meskipun mungkin milik benda itu kemudian jatuh ketangan orang. Hari Effendy, "Perlindungan Hukum Kepada Kreditur
}

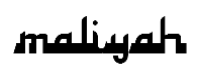

Jurnal Hukum Bisnis Islam

Volume 8, Nomor 2, Desember 2018 p-ISSN: 2088-4869/ e-ISSN: 2597-4351 
pakai, melainkan untuk menjamin piutangnya dengan mengambil penggantian dari benda tersebut guna membayar piutangnya.

2. Hak gadai bersifat accessoir. Hak gadai merupakan hak tambahan atau accessoir, yang ada dan tidaknya tergantung dari ada dan tidaknya piutang yang merupakan perjanjian pokoknya. Dengan demikian hak gadai akan hapus jika perjanjian pokoknya hapus.

3. Hak gadai tidak dapat dibagi-bagi. Karena hak gadai tidak dapat dibagi-bagi, maka dengan dibayarnya sebagian hutang tidak akan membebaskan sebagian dari benda gadai

4. Hak gadai adalah hak yang didahulukan. Piutang dengan hak gadai mempunyai hak untuk didahulukan daripada piutangpiutang lainnya, maka kreditor pemegang gadai mempunyai hak mendahulu (droit de preference).

5 . Benda yang menjadi obyek gadai adalah benda bergerak baik yang bertubuh maupun tidak bertubuh. ${ }^{7}$

\section{Hak dan Kewajiban Pemegang Gadai}

Ada beberapa hak yang harus dimiliki oleh para pemegang gadai, diantaranya adalah hak untuk menjual dan menahan barang gadai, hak kompensasi dang anti rugi, hak penguasaan barang, hak preverensi, serta hak untu menagih dan menerima piutang:

1. Hak untuk menjual benda gadai atas kekuasaan sendiri atau mengeksekusi benda gadai. ${ }^{8}$ Dalam Pasal 1155 KUH Perdata disebutkan bahwa: "Apabila oleh para pihak tidak telah diperjanjikan lain, jika si berutang atau si pemberi gadai wanprestasi, maka si kreditor berhak menjual barang gadai

Pemegang Gadai Dan Pihak Ke III Dalam Perjanjian Gadai Terhadap Barang Jaminan Di Perum Pegadaian Kota Semarang" (Tesis-Universitas Diponegoro, 2008), 15.

7 Tri Pudji Susilowati, "Pelaksanaan Gadai Dengan Sistem Syariah Di Perum Pegadaian Semarang" (Universitas Diponegoro, 2008).

8 Gabriel Moningka, "Hak PT. Pegadaian Melaksanakan Pelelangan Barang Emas," Lex Privatum 1, no. 2 (2013), 191. 
dengan maksud untuk mengambil pelunasan piuiang pokok, bunga dan biaya dari pendapatan penjualan tersebut."

2. Hak untuk menahan benda gadai. Pasal 1159 ayat (1) KUHPerdata menyatakan: "Dalam hal pemegang gadai tidak menyalahgunakn benda gadai, maka si berhutang tidak berkuasa untuk menuntut pengembaliannya, sebelum ia membayar seoenuhnya baik utang pokok, maupun bunga dan biaya hutangnya yang untuk menjaminnya barang gadai telah diberikan, beserta segala biaya yang telah dikeluarkan untuk menyelamatkan barang gadai." Ketentuan ini memberi wewenang kepada pemegang gadai untuk menahan benda gadai selama debitor belum melunasi hutangnya.

3. Hak Kompensasi. Hak ini erat hubungannya dengan hutang kedua sebagaimana dimaksud dalam Pasal 1159 ayat (2) KUH Perdata: "Apabila guna melunasi piutang pertama si kreditor telah mengeksekusi benda gadai, maka dari hasil pendapatan lelang kreditor dapat mengambil lebih dahulu sejumlah uang yang sama banyaknya dengan piutang pertama yang dijamin dengan gadai. Jika ada sisa, maka diserahkan kepada debitor. Apabila sisa tersebut tidak diserahkan kepada dabitor, maka kreditor berhutang kepada debitor."

Dalam Pasal 1425 disebutkan bahwa: "Jika dua orang saling berhutang satu kepada yang lain, maka terjadilah antara mereka suatu perjumpaan hutang, dengan mana hutanghutang antara kedua orang tersabut dihapuskan." Berdasarkan ketentuan tersebut, maka pemegang gadai dapat mengkompensasikan piutangnya yang kedua dengan hutangnya (sisa penjualan lelang benda gadai) kepada debitor.

4. Hak untuk mendapatkan ganti rugi atas biaya uang telah dikeluarkan untuk menyelamatkan benda. Pasal 1157 ayat (2) KUH Perdata menentukan bahwa yang harus diganti oleh debitor adalah biaya-biaya yang berguna dan perlu yang telah dikeluarkan guna keselamatan barang gadai. Selama biaya-biaya itu belum dibayar, maka si kraditor tidak 
diwajibkan untuk mengembalikan barang gadai kepada debitor. Di sini kreditor mempunyai hak retensi juga.

5. Hak untuk menjual dalam kepailitan debitor. Jika debitor pailit, maka kreditor pemegang gadai dapat melaksanakan hak-haknya, seolah-olah tidak terjadi kepailitan. Dengan demikian hak kreditor untuk melakukan parate eksekusi berkurang dengan terjadinya kepailitan debitor. Hak untuk menjual barang gadai harus dilakukan dalam jangka waktu 2 (dua) bulan setelah debitor dinyatakan pailit, kecuali jika tenggang waktu tersebut diperpanjang oleh hakim.

6. Hak preferensi. Kreditor pemegang gadai rnampunyai hak untuk didahulukan dalam pelunasan piutangnya daripada krediter-kreditor yang lain. Atas izin hakim tetap menguasai benda gadai. Pemegang gadai dapat menuntut agar benda gadai akan tetap pada pemegang gadai untuk suatu jumlah yang akan ditetapkan dalam vonnis hingga sebesar hutangnya beserta bunga dan biaya (Pasal 1156 ayat (1) KUHPerdata). Hal ini berarti bahwa barang gadai dibeli oleh kreditor dengan harga pantas menurut pendapat hakim.

7. Hak untuk menjual benda gadai dengan perantaraan hakim. Penjualan benda gadai untuk mengambil pelunasan piutang dapat juga terjadi jika si berpiutang menuntut di muka hakim supaya barang gadai dijual menurut cara-cara yang ditentukan oleh hakim untuk melunasi hutang pokok beserta bunga dan biaya. Hal ini biasanya terjadi jika benda gadai berupa benda antik.

8. Hak untuk menerima bunga piutang gadai. Hak ini berdasarkan Pasal 1158 KUHPerdata yang menentukan bahwa: "Pemegang gadai dari suatu piutang yang menghasilkan bunga, berhak menerima bunga itu, dengan kewajiban memperhitungkan dengan bunga piutang yang harus dibayarkan kepadanya."

9. Hak untuk menagih piutang gadai. Hak ini dilakukan dengan cara pemberian kuasa yang tidak dapat dicabut kembali dari pemberi gadai kepada pemegang gadai untuk managih dan menerima pembayaran dari debitor yang hutang-hutangnya 
digadaikan. Pemberian kuasa ini dicantumkan dalam perjanjian gadai. ${ }^{9}$

Adapun kewajiban-kewajian dari pemegang gadai adalah sebagai berikut:

1. Kewajiban memberitahukan kepada pemberi gadai jika barang gadai dijual. Pemberitahuan dengan telegraf atau surat tercatat berlaku sebagai pemberitahuan yang sah (Pasal 1156 ayat (3) KUHPerdata)

2. Kewajiban memelihara benda gadai

Kewajiban memelihara benda gadai ini dapat disimpulkan dari bunyi Pasal 1157 ayat (1) dan Pasal 1159 ayat (1) KUHPerdata. Dalam Pasal 1157 ayat (1) KUHPerdata ditentukan bahwa: "Pemegang gadai bertanggung jawab atas hilangnya atau merosotnya barang gadai, sekedar itu telah terjadi karena kelalaiannya." Begitu juga pemegang gadai tidak boleh menyalahgunakan benda gadai (Pasal 1159 ayat (1) KUHPerdata).

3. Kewajiban untuk memberikan perhitungan antara hasil penjualan barang gadai dengan ebsarnya piutang kepada pemberi gadai.

4. Kewajiban untuk mengembalikan barang gadai. Kewajiban ini dapat diketahui dari bunyi Pasal 1159 ayat (1) KUHPerdata, yaitu apabila:

a. Kreditor telah menyalahgunakan barang gadai;

b. Debitor telah melunasi sepenuhnya, baik utang pokok, bunga dan biaya hutangnya serta biaya untuk menyelamatkan barang gadai

5. Kewajiban untuk memperhitungkan hasil penagihan bunga piutang gadai dengan besarnya bunga piutangnya kepada debitor.

6. Kewajiban untuk mengembalikan sisa hasil penagihan piutang gadai kepada pemberi gadai. ${ }^{10}$

\footnotetext{
9 Joni Oktavianto, R. Suharto, and Triyono, “Anggung Jawab PT. Pegadaian (Persero) Atas Kerusakan Dan Kehilangan Barang Gadai Di PT. Pegadaian (Persero) Kota Semarang," Diponegoro Law Journal 5, no. 3 (2016), 9-10. ${ }^{10}$ Ibid
} 


\section{Berakhirnya Gadai}

Hak gadai bisa berakhir jika disebabkan oleh beberapa hal berikut, yaitu:

1. Karena hapusnya perikatan pokok. Hak gadai adalah hak accessoir, maka dengan hapusnya perikatan pokok membawa serta hapusnya hak gadai.

2. Karena benda gadai keluar dari kekuasaan pemegang gadai. Pasal 1152 ayat (3) KUHPerdata menentukan bahwa: "Hak gadai hapus apabila barang gadai keluar dari kebiasaan si pemegang gadai". Namun demikian hak gadai tidak menjadi hapus apabila pemegang gadai kehilangan kekuasaan atas barang gadai tidak dengan suka rela (karena hilang atau dicuri). Dalam hal ini jika ia memperoleh kembali barang gadai tersebut, maka hak gadai dianggap tidak pernah hilang.

3. Karena rusaknya benda gadai. Tidak adanya obyek gadai mengakibatkan tidak adanya hak kebendaan yang semula membebani benda gadai, yaitu hak gadai.

4. Karena penyalahgunaan benda gadai. Pasal 1159 ayat (1) KUHPerdata menyebutkan bahwa: "Apabila kreditor menyalahgunakan benda gadai, pemberi gadai berhak menuntut pengembalian benda gadai." Dengan dituntutnya kembali benda gadai oleh pemberi gadai maka hak gada yang dipunyaj pemegang gadai menjadi hapus, apabila pemegang gadai menyalahgunakan benda gadai.

5. Karena pelaksanaan eksekusi benda gadai.11 Dengan dilaksanakannya eksekusi terhadap benda gadai, maka benda gadai berpindah ke tangan orang lain. Oleh karena itu maka hak gadai menjadi hapus.12

11 Yandi Novia, "Hak Gadai" (Palangkaraya: Universitas Muhammadiyah Palangkaraya, 2014), 6.

12 Pasal 1155 dan Pasal 1156 telah mengatur pelaksanaan eksekusi atas benda gadai yaitu menjual benda gadai di muka umum, terhadap benda pergadangan atau efek dapat dijual di pasar atau di bursa, penjualan menurut cara yang ditentukan hakim, dan larangan untuk menjanjikan klausal milik beding dalam perjanjian gadai. Tokichi K. Mait, "Tinjauan Yuridis Terhadap Eksekusi Gadai 
6. Karena kreditor melepaskan benda gadai secara sukarela. Pasal 1152 ayat (2) KUHPerdata menyebutkan bahwa. "Tak ada hak gadai apabila barang gadai kembali dalam kekuasaan pemberi gadai."

7. Karena percampuran. Percampuran terjadi apabila piutang yang dijamin dengan hak gadai dan benda gadai berada dalam tangan satu orang. Dalam hal ini terjadi percampuran, maka hak gadai menjadi hapus. Orang tidak mungkin mempunyai hak gadai atas benda miliknya sendiri.

\section{Konsep Gadai secara Syariah}

Pengertian Kata gadai dalam bahasa Arab disebut dengan ar-rahn. Kata tersebut menurut arti aslinya adalah tetap atau lestari. Kata ar-rahn adalah bentuk masdar dari rahanayarhanu-rahn yang artinya menggadaikan atau menungguhkan. Dari segi bahasa ar-rahn mempunyai dua makna yaitu al-tsubut wa al-dawam yang berarti tetap dan kekal, sedangkan arti lainnya al-habs (menahan).

Secara istilah terdapat berbagai macam pengertian gadai menurut para ulama. Menurut Sayyid Sabiq gadai adalah menjadikan barang yang mempunyai nilai harta menurut pandangan syara' sebagai jaminan hutang, sehingga orang yang bersangkutan boleh mengambil seluruh atau sebagian hutang tersebut karena adanya barang. ${ }^{13}$ Ulama Syafii dan Hambali mengartikan rahn dengan menjadikan materi (barang) sebagai jaminan utang, yang dapat dijadikan pembayar utang apabila orang yang berhutang tidak bisa membayar hutangnya. ${ }^{14}$

Menurut Ibnu Qudamah yang dimaksud dengan gadai adalah suatu benda yang dijadikan kepercayaan dari suatu hutang untuk dipenuhi dari harganya, maka benda itu dapat dijadikan alat pembayar hutang. Gadai menurut Ahmad Azhar

Dan Perlindungan Hukum Menurut Hukum Positif Di Indonesia," Lex Et Societatis 7, no. 9 (n.d.), 46.

${ }^{13}$ Muhammad Syafii Antonio, Bank Syariah: Dari Teori Ke Praktik (Jakarta: Gemma Insani, 2001), 128.

${ }^{14}$ Rahma Amir, "Gadai Tanah Perspektif Ekonomi Islam," Jurnal Muamalah 5, no. 1 (2015), 85 . 
Basyir adalah menjadikan sesuatu benda bernilai menurut pandangan syara' sebagai tanggungan hutang; dengan adanya benda yang menjadi tanggungan itu seluruh atau sebagian hutang dapat diterima. ${ }^{15}$

Dari definisi di atas, dapat dikatakan bahwa yang dimaksud dengan gadai ( $r a h n)$ menurut syariat adalah menjadikan barang yang mempunyai nilai harta sebagai jaminan hutang. Dalam arti seluruh hutang atau sebagiannya dapat diambil karena sudah ada barang yang dijadikan jaminan, dan dapat dijadikan pembayaran hutang jika hutang itu tidak dapat dibayar.

Gadai berarti penahanan atau pengekangan, sehingga dengan akad gadai menjadikan kedua belah pihak mempunyai tanggung jawab bersama. Yang punya hutang bertanggung jawab untuk melunasi hutangnya, sedangkan orang yang berpiutang bertanggung jawab untuk menjamin keutuhan barang jaminan. Apabila hutang itu telah dibayar, maka penahanan atau pengekangan oleh sebab akad itu menjadi berakhir. Sehingga penerima gadai dan pemberi gadai bebas dari tanggung jawab masing-masing.

Ulama bersepakat bahwa rahn merupakan transaksi yang diperbolehkan. Meskipun demikian ada beberapa golongan ulama yang mengharamkan praktik gadai, apalagi jika diterapkan dalam perbankan syariah. Alasan-alasan pengharaman gadai antara lain: Pertama, karena dianggap telah terjadi penggabungan dua akad menjadi satu akad (multi akad) yang dilarang syariah, yaitu akad gadai (atau akad qardh) dan akad ijarah (biaya simpan). Diriwayatkan oleh Ibnu Mas'ud RA, bahwasanya Nabi SAW telah melarang dua kesepakatan dalam satu kesepakatan. (HR Ahmad, hadis sahih).

Kedua, karena dianggap telah terjadi riba walaupun disebut dengan istilah "biaya simpan" atas barang gadai dalam akad qardh (utang). Padahal qardh yang menarik manfaat, baik

\footnotetext{
${ }^{15}$ Masmuah and Sukresno, "Tinjauan Yuridis Implementasi Gadai Syariah Pada Kantor Bank BRI Syariah Kudus," Jurnal Sosial Dan Budaya 6, no. 1 (2013), 43.
} 
berupa hadiah barang, uang, atau manfaat lainnya adalah riba yang hukumnya haram. Sabda Rasulullah SAW,"Jika seseorang memberi pinjaman (qardh), janganlah dia mengambil hadiah." (HR Bukhari, dalam kitabnya At Tarikh Al Kabir).

Ketiga, karena dianggap telah terjadi kekeliruan pembebanan biaya simpan. Dalam kasus ini, dikarenakan pihak murtahin yang berkepentingan terhadap barang gadai sebagai jaminan atas utang yang diberikannya, maka seharusnya biaya simpan menjadi kewajiban murtahin, bukan kewajiban rahin (nasabah). Sabda Rasulullah SAW, "Jika hewan tunggangan digadaikan, maka Murtahin harus menanggung makanannya, dan (jika) susu hewan itu diminum, maka atas yang meminum harus menanggung biayanya." (HR Ahmad, Al Musnad, 2/472). ${ }^{16}$

Meskipun ada pertentangan pada sebagian para ulama, pada kesimpulannya hukum ar-rahn (gadai) tetap diperbolehkan, sebab sebagian jumhur ulama telah memperbolehkannya, dan tidak mungkin para ulama bersepakat untuk membuat suatu hukum yang bertentangan dengan syariat Islam. Apalagi jika dengan adanya gadai dapat memberikan kemudahan dan pertolongan bagi masyarakat pada umumnya.

Ada beberapa rukun dalam akad rahn, yaitu; adanya orang yang menggadaikan (ar-rahin), barang-barang yang digadai (marhun), orang yang menerima gadai (murtahin), dan sesuatu yang karenanya diadakan gadai, yakni harga, dan sifat akad rahn.

Berkaitan dengan sahnya akad rahn, ada beberapa syarat yang harus dipenuhi oleh para pihak yang terlibat dalam akad ini yakni: berakal, baligh, barang yang dijadikan jaminan ada pada saat akad, serta barang jaminan dipegang oleh orang yang menerima gadai (marhun) atau yang mewakilinya. ${ }^{17}$

\footnotetext{
16 "Hukum Gadai Syariah," Taukhid.Wordpress.Com, 2012, http://taukhid.wordpress.com/2012/05/22/hukum-gadai-syariah/.

17 "Manajemen Pegadaian Konvensional vs Syariah," n.d., http://www.scribd.com/doc/6429241/Manajemen-Pegadaian-Konvensional-vsSyariah pada tanggal 21 Juni 2012.
} 


\section{Landasan Hukum Gadai dalam Syariah}

Dasar hukum gadai dalam Islam berasal dari Al-Qur'an dan Hadis sebagaimana berikut:

1. Al Qur'an: Al-Baqarah ayat 283:

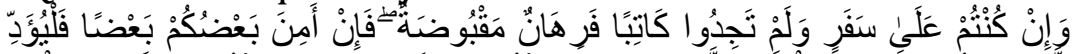

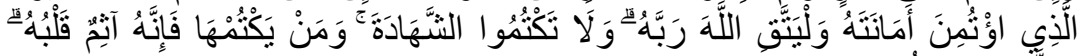

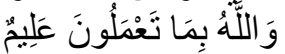

Artinya: "Jika kamu dalam perjalanan (dan bermu'amalah tidak secara tunai) sedang kamu tidak memperoleh seorang penulis, maka hendaklah ada barang tanggungan yang dipegang (oleh yang berpiutang). Akan tetapi jika sebagian kamu mempercayai sebagian yang lain, maka hendaklah yang dipercayai itu menunaikan amanatnya (hutangnya) dan hendaklah ia bertakwa kepada Allah Tuhannya; dan janganlah kamu (para saksi) menyembunyikan persaksian. Dan barangsiapa yang menyembunyikannya, maka sesungguhnya ia adalah orang yang berdosa hatinya; dan Allah Maha Mengetahui apa yang kamu kerjakan."

2. Hadis

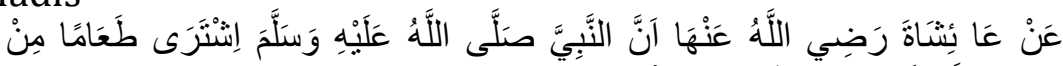

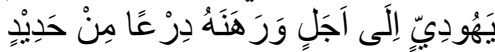

Artinya: "Aisyah r.a. berkata bahwa Rasulullah membeli makanan dari seorang Yahudi dan menjaminkan kepadanya baju besi."18

3. Fatwa DSN MUI

Islam memperbolehkan adanya gadai karena sudah jelas ada dalil dan hadis yang memperbolehkannya, selain itu juga dikarenakan manfaat yang ditimbulkannya. DSN sendiri juga telah mengeluarkan fatwa tentang ar-rahn, yaitu fatwa Nomor: 25/DSN-MUI/III/2002.19 Fatwa ini membolehkan gadai dengan beberapa ketentuan. Yaitu: Pertama, Murtahin

\footnotetext{
${ }^{18}$ HR Bukhari No. 1926, Kitab Al-Buyu, Dan Muslim.

${ }^{19}$ Ahmad Kamil and M. Fauzan, Kitab Undang-Undang Hukum Perbankan Dan Ekonomi Syariah (Jakarta: Prenada Media, 2007).
} 
(penerima barang) mempunyai hak untuk menahan Marhun (barang) sampai semua hutang Rahin (yang menyerahkan barang) dilunasi, Marhun dan manfaatnya tetap menjadi milik Rahin. Kedua, pada prinsipnya, Marhun tidak boleh dimanfaatkan oleh Murtahin kecuali seizing Rahin, dengan tidak mengurang nilai Marhun dan pemanfaatannya itu sekedar pengganti biaya pemeliharaan dan perawatan. ${ }^{20}$ Ketiga, Pemeliharaan dan penyimpanan Marhun pada dasarnya menjadi kewajiban Rahin, namun dapat dilakukan juga oleh Murtahin, sedangkan biaya dan pemeliharaan penyimpanan tetap menjadi kewajiban Rahin. Keempat, besarnya biaya pemeliharaan dan penyimpanan Marhun tidak boleh ditentukan berdasarkan jumlah pinjaman. Kelima, penjualan Marhun. Apabila jatuh tempo, Murtahin harus memperingatkan Rahin untuk segera melunasi hutangnya. Apabila Rahin tetap tidak bisa melunasi hutangnya, maka Marhun dijual paksa. Hasil penjualan Marhun digunakan untuk melunasi hutang, biaya pemeliharaan dan penyimpanan yang belum dibayar serta biaya penjualan. Kelebihan hasil penjualan menjadi milik Rahin dan kekurangannya menjadi kewajiban Rahin dan kekurangannya juga menjadi milik Rahin.

Gadai tidak hanya diberlakukan ketika bepergian. Meskipun zahir ayat al-Qur'an menganjurkan rahn ketika bepergian namun banyak hadis yang membolehkan rahn meski

${ }^{20}$ Menurut ulama Hanafiyah, sesuai dengan fungsi dari barang gadai sebagai jaminan dan kepercayaan bagi penerima gadai, maka barang gadai dikuasai oleh penerima gadai. Apabila barang tersebut tidak dimanfaatkan oleh penerima gadai, maka berarti menghilangkan manfaat barang tersebut, padahal barang gadai tersebut memerlukan biaya untuk pemeliharaan. Menurut Sayyid Sabiq memanfaatkan barang gadai tidak diperbolehkan meskipun seizin orang yang menggadaikan. Tindakan orang yang memanfaatkan harta benda gadai tidak ubahnya qiradh, dan setiap bentuk qiradh yang mengalirkan manfaat adalah riba. Kecuali barang yang digadaikan berupa hewan ternak yang bisa diambil susunya, kemudian pemilik barang memberikan izin untuk memanfaatkan barang tersebut, maka penerima gadai boleh memanfaatkanya. Dwi Febriani, "Konsep Gadai Dan Pemanfaatan Barang Gadai Menurut Sayyid Sabiq" (Universitas Islam Negeri Sultan Syarif Kasim Riau, 2011), iii. 
tidak sedang bepergian. ${ }^{21}$ Bolehnya pegadaian ketika tidak bepergian dikuatkan oleh hadis Aisyah Ra yang mengatakan bahwa Nabi saw menggadaikan perisai perangnya ketika beliau sedang berada di Madinah. ${ }^{22}$ Dan bolehnya pegadaian ketika sedang safar dan tidak safar dikuatkan oleh makna gadai itu sendiri yang artinya adalah "barang yang dijadikan sebagai jaminan hutang". Ini adalah isyarat inti dari pegadaian ialah untuk jaminan, sama saja ketika bepergian atau tidak bepergian.

\section{Barang yang Boleh Digadaikan}

Rahn yang diatur menurut prinsip syariah terdapat 2 macam: ${ }^{23}$ Pertama, Rahn 'Iqar/Rasmi (rahn Takmini/Rahn Tasjily), yaitu bentuk gadai, dimana barang yang digadaikan hanya dipindahkan kepemilikannya, namun barangnya sendiri masih tetap dikuasai dan dipergunakan oleh pemberi gadai. Kedua, Rahn Hiyazi, yaitu bentuk Rahn Hiyazi inilah yang sangat mirip dengan konsep gadai baik dalam hukum adat maupun dalam hukum positif. Jadi berbeda dengan Rahn 'Iqar yang hanya menyerahkan hak kepemilikan atas barang, maka pada Rahn Hiyazi tersebut, barangnya pun dikuasai oleh Kreditur.

Sebagaimana halnya dengan gadai berdasarkan hukum positif, barang yang digadaikan bisa berbagai macam jenisnya, baik bergerak maupun tidak bergerak. Dalam hal yang digadaikan berupa benda yang dapat diambil manfaatnya,

\footnotetext{
21 Abu Ibrahim Muhammad Ali, "Hukum Gadai Dalam Al-Qur'an Dan AlHadits," Syifa-Alqulub.Blogspot.Com, 2012, http://syifaalqulub.blogspot.com/2012/04/hukum-gadai-dalam-al-quran-dan-hadist.html.

22 Sistem gadai yang ada pada saat ini merupakan suatu jenis transaksi yang dipraktekkan oleh Nabi Muhammad SAW., ketika itu nabi melakukan transaksi gadai pada saat beliau di Madinah, dan pada saat itu nabi tidak mempunyai uang tunai untuk membeli gandum, maka praktek yang dilakukan adalah dengan cara menggadaikan baju besi beliau kepada orang yahudi untuk dijadikan jaminan hutangnya. Novi Rofiani, "Perilaku Nasabah Dalam Memilih Produk Pembiayaan Pegadaian Pada PT. Bank Syari'ah Mandiri TBK," Al-Iqtishad 1, no. 2 (2009), 147.

${ }^{23}$ Irma Devita, “Jenis-Jenis Gadai,” 2012, http://irmadevita.com/tag/gadai.
} 
maka penerima gadai dapat mengambil manfaat tersebut dengan menanggung biaya perawatan dan pemeliharaannya.

Segala sesuatu yang boleh diperjualbelikan, boleh dijadikan barang gadai/jaminan, sedangkan yang tidak boleh diperjualbelikan maka tidak boleh digadaikan. Hal ini dikarenakan maksud menggadaikan sesuatu adalah untuk jaminan apabila tidak dapat melunasi hutangnya, sehingga apabila penggadai (pemilik barang) tidak bisa melunasi hutangnya, maka barang tersebut bisa dijual untuk melunasi hutang tersebut, dan ini akan terwujud dengan barang yang bisa diperjualbelikan.

Oleh karena itu, dilarang menggadaikan anaknya, karena anak tidak boleh diperjualbelikan. Sebagaimana sabda Nabi saw: "Ada tiga golongan yang dibantah oleh Allah pada hari kiamat." Diantara tiga golongan tersebut, Nabi saw menyebutkan: Dan (Allah akan membantah) seorang yang menjual (orang) yang merdeka[3] dan memakan hasil penjualannya. (HR. Bukhari 4/447 no. 2270)

Dilarang pula menggadaikan hewan piaraan yang haram hukumnya seperti anjing dan babi, karena anjing dan babi tidak boleh diperjualbelikan. Hal ini didasari oleh sebuah hadis Nabi saw:

"Sesungguhnya Allah apabila mengharamkan sesuatu, pasti mengharamkan harga (jual beli)nya". (Hadis ini dishahihkan al-Albani dalam Ghayatul Maram).

Selain itu dilarang menggadaikan benda wakaf, karena tidak boleh dijual. Sebagaimana hadis yang diriwayatkan Ibnu Umar bahwa Nabi saw bersabda:

"Tidak boleh dijual barang asal (yang diwakafkan) tidak boleh dihibahkan dan tidak boleh diwariskan". ${ }^{24}$

Dari contoh-contoh di atas, dapat kita ketahui bahwa setiap barang yang bisa / boleh diperjualbelikan maka boleh dijadikan barang gadai.

Berkaitan dengan pemegang barang gadai, pada dasarnya, yang berhak memegang barang gadai adalah yang memberi

${ }^{24}$ HR. Bukhari 2737, Muslim 1632, Tirmidzi 1375. 
pinjaman kepada penggadai barang. Hal tersebut harus didasari rasa saling percaya, namun seandainya salah satu dari mereka merasa tidak aman dan tidak rela barangnya dipegang oleh orang yang meminjami sesuatu tadi, maka barang tersebut dipegang oleh pihak ketiga yang telah disepakati oleh kedua belah pihak.

\section{Pemanfaatan dan Penjualan Barang Gadai}

Jumhur ulama, kecuali mazhab Hanbali bersepakat bahwa barang yang sedang digadaikan tidak boleh dimanfaatkan oleh pemegang barang kecuali dengan seizin pemilik barang. Hal ini disebabkan karena pemegang barang tidak memilikinya, bahkan barang tersebut sekedar amanah, sehingga tidak berhak memanfaatkannya. Hal ini didasari oleh sabda Nabi Muhammad saw:

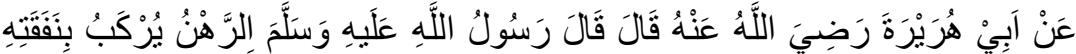

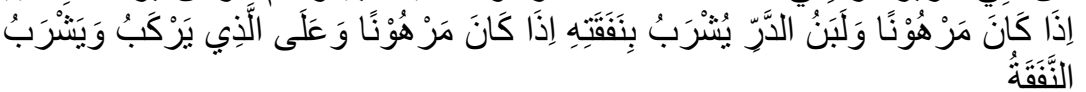

Artinya: Abu Hurairah r.a. berkata bahwa Rasulullah saw. Bersabda: "Apabila ada ternak digadaikan, punggungnya boleh dinaiki (oleh orang yang menerima gadai) karena ia telah mengeluarkan biaya (menjaga)nya. Apabila ternak itu digadaikan, air susunya yang deras boleh diminum (oleh orang yang menerima gadai) karena ia telah mengeluarkan biaya (menjaga)nya. Kepada orang yang naik dan minum, ia harus mengeluarkan biaya (perawatan)nya". ${ }^{25}$

Seandainya pemegang barang terlanjur memanfaatkannya, serta menjual atau menyewakannya tanpa seizin pemiliknya, maka menurut Imam Syafi'i dan Imam Hanbali penjualan dan sewa-menyewa tersebut batal dan tidak sah. Adapun menurut Imam Hanafi dan Imam Malik, penjualan dan sewa menyewa tersebut hukumnya tergantung kepada pemilik barang, apabila ketika pemilik barang mengetahui

\footnotetext{
${ }^{25}$ Rachmat Syafe'i, Fiqih Muamalah (Bandung: Pustaka Setia, 2001), 159.
} 
kemudian menyetujui, maka sah penjualan atau sewa menyewa itu, apabila tidak maka batal dan tidak sah.

Pendapat terakhir inilah (Imam Hanafi dan Imam Malik) yang kuat dengan dasar sebuah hadist yang dikeluarkan oleh Imam Bukhari, bahwasanya seorang sahabat bernama Urwah al-Bariqi ra pernah dititipi Rasulullah saw satu dinar untuk membeli satu ekor kambing qurban, lalu Urwah pergi ke pasar hewan membeli dua ekor kambing seharga satu dinar, kemudian sebelum kembali kepada Nabi saw, ia menjual satu ekor kambing seharga satu dinar, lalu datang kepada beliau membawa satu ekor kambing dan uang satu dinar, dan tatkala Nabi saw mengetahuinya, beliau tidak mengingkarinya, bahkan Nabi saw menyetujui dan mendo'akan keberkahan buat Urwah.

Adapun kerugian atau keuntungan yang muncul dari barang yang sedang digadaikan dan sedang berada di tangan pemegang barang, maka semuanya dikembalikan kepada penggadai (pemilik barang) yang asli. Hal ini didasari sabda Nabi Muhammad saw:

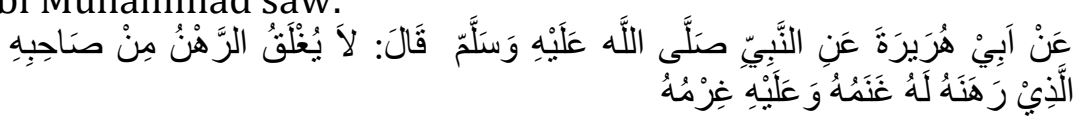

Artinya: "Abu Hurairah r.a berkata bahwasanya Rasulullah SAW bersabda, "Barang yang digadaikan itu tidak boleh ditutup dari pemilik yang menggadaikannya. Baginya adalah keuntungan dan tanggung jawabnyalah bila ada kerugian (atau biaya)," (HR Syafi'i dan Daruqutni)

\section{Jatuh Tempo Pembayaran Hutang}

Jika telah datang waktu (jatuh tempo) yang disepakati untuk pembayaran hutang, maka ada beberapa kemungkinan yang terjadi, antara lain:

Apabila telah jatuh tempo pembayaran hutang dan penggadai (pemilik barang) telah mendapati/mempunyai harta untuk melunasi hutangnya, maka dia harus bersedia membayar hutangnya, dan mengambil kembali barang gadai yang telah dijadikan sebagai jaminannya. Karena inilah kewajiban setiap 
orang yang mempunyai tanggungan, menepati perjanjian dan tidak mengingkarinya.

Apabila penggadai (pemilik barang) tidak bisa melunasinya disebabkan ketidakmampuannya, maka disyari'atkan bagi pemegang barang untuk bersabar menunggu sampai penggadai (pemilik barang) mampu dan bisa membayar hutangnya, sedangkan penggadai (pemilik barang) harus berusaha mendapatkan harta untuk melunasi hutangnya karena ini merupakan tanggungannya.

Apabila penggadai (pemilik barang) tidak mau melunasi hutangnya padahal dia dalam keadaan lapang atau mampu untuk melunasi hutangnya, maka hakimlah yang menghukumi masalah ini. Dan barang gadai harus dijual lantas hasil penjualannya dipakai untuk melunasi hutangnya, walaupun penggadai atau pemilik barang tidak rela barangnya dijual. Hal ini telah disepakati oleh para fuqoha (ahli fiqh). ${ }^{26}$

Allah mensyariatkan ar-rahn (gadai) untuk kemaslahatan manusia, khususnya orang yang menggadaikan (rahin) dan pemberi utangan (murtahin). Rahin mendapatkan keuntungan berupa dapat menutupi kebutuhannya, sehingga menyelamatkannya dari krisis, menghilangkan kegundahan di hatinya, serta terkadang ia bisa berdagang dengan modal tersebut, yang dengan itu menjadi sebab ia menjadi kaya.

Adapun murtahin (pihak pemberi utang), dia akan menjadi tenang serta merasa aman atas haknya, dan dia pun mendapatkan keuntungan syar'i. Bila ia berniat baik, maka dia mendapatkan pahala dari Allah. Adapun kemaslahatan yang kembali kepada masyarakat, yaitu memperluas interaksi perdagangan dan saling memberikan kecintaan dan kasih sayang di antara manusia, karena ini termasuk tolongmenolong dalam kebaikan dan takwa. Terdapat manfaat yang menjadi solusi dalam krisis, memperkecil permusuhan, dan melapangkan penguasa.

\section{Praktik Rahn dalam Perbankan Syariah}

${ }^{26}$ Kasyful Qana. Al-Fiqhul Islami.hal.275 
Dewasa ini kontrak ar-rahn dalam Perbankan Syariah tidak hanya dipakai sebagai produk pelengkap. Akan tetapi, terdapat beberapa bank Syariah yang telah menyediakan produk ar-rahn (gadai) sebagai produk tersendiri, ${ }^{27}$ di mana produk ini sangat bermanfaat bagi nasabah untuk melayani kebutuhan nasabah guna keperluan yang bersifat jasa dan konsumtif, seperti pendidikan, kesehatan dan sebagainya. Pinjaman tersebut menggunakan akad pembiayaan ar-rahn.

Pembiayaan ar-rahn adalah menahan sesuatu dengan cara yang dibenarkan yang memungkinkan untuk ditarik kembali, yaitu menjadikan barang yang mempunyai nilai harta menurut pandangan syariah sebagai jaminan hutang, sehingga orang yang bersangkutan boleh mengambil utang semuanya atau sebagian. Dengan kata lain, ar-rahn adalah akad menggadaikan barang dari satu pihak kepada pihak lain dengan hutang sebagai gantinya. ${ }^{28}$

Dalam praktik, yang biasanya diserahkan secara rahn adalah benda-benda bergerak, khususnya emas dan kendaraan bermotor. Rahn dalam bank syariah juga biasanya diberikan sebagai jaminan atas qardh atau pembiayaan yang diberikan oleh bank syariah kepada nasabah. rahn juga dapat diperuntukkan bagi pembiayaan yang bersifat konsumtif seperti pembayaran uang sekolah, modal usaha dalam jangka pendek, untuk biaya pulang kampung pada waktu lebaran dan lain sebagainya. Jangka waktu yang pendek (biasanya 2 bulan) dan dapat diperpanjang atas permintaan nasabah. ${ }^{29}$

Akad ar-rahn dapat dikategorikan dalam akad tabarru'. Akad tabarru' adalah segala macam perjanjian yang menyangkut not-for profit transaction (transaksi nirlaba). ${ }^{30}$ Karena bank atau Lembaga keuangan tidak menarik manfaat

\footnotetext{
27 Adang Sudjana, "Bank Syariah Sebagai Alternatif," The Winners 4, no. 1 (2003): 46-53.

${ }^{28}$ Yutisa Tri Cahyani, "Konsep Fee Based Services Dalam Perbankan Syariah," El Barka: Journal of Islamic Economics and Business 1, no. 2 (2018), 245.

${ }^{29}$ Irma Devita, "Jenis-Jenis Gadai," 2012, http://irmadevita.com/tag/gadai.

${ }^{30}$ Nurul Ichsan, “Akad Bank Syariah,” Asy-Syir'ah: Jurnal Ilmu Syari'ah Dan Hukum 50, no. 2 (2016), 404.
} 
apapun kecuali biaya pemeliharaan dan penaksiran barang yang digadaikan. Berbeda dengan pegadaian konvensional yang menggunakan sistem bunga.

Namun tren dari perkembangan ar-rahn sebagai produk perbankan syariah belum begitu baik. Hal ini disebabkan oleh keberadaan komponen-komponen pendukung produk ar-rahn yang terbatas. ${ }^{31}$ Oleh karena itu, tidak semua bank mampu memfasilitasi ar-rahn ini. Tetapi jika keberadaan ar-rahn sangat dibutuhkan dalam sistem pembiayaan bank, maka bank tersebut memiliki ketentuan sendiri mengenai ar-rahn.

\section{Penutup}

Berdasarkan pembahasan di atas dapat disimpulkan bahwa gadai atau rahn diatur dalam KUHPerdata dan hukum Islam. Gadai dalam KUHPerdata diatur pada Buku II Bab 20 Pasal 1150 sampai dengan Pasal 1161 KUHPerdata. Pengertian gadai menurut KUHPerdata adalah suatu hak yang diperoleh seorang berpiutang atas suatu barang bergerak, yang diserahkan kepadanya oleh seorang berutang atau oleh orang lain atas namanya, dan yang memberikan kekuasan kepada si berpiutang itu untuk mengambil pelunasan dari barang tersebut secara didahulukan daripada orang-orang berpiutang lainnya, dengan kekecualian biaya untuk melelang barang tersebut dan biaya yang telah dikeluarkan untuk menyelamatkannya setelah barang itu digadaikan, biaya-biaya mana harus didahulukan.

Dalam KUHPerdata juga dijelaskan pasal-pasal tentang sifat gadai, hak dan kewajiban pemegang gadai dan berakhirnya gadai.

Dalam hukum Islam, pengertian gadai memiliki kesamaan dengan KUHPerdata, bahwa gadai merupakan adanya jaminan akibat adanya hutang piutang. Islam memperbolehkan gadai didasarkan pada dalil-dalil yang bersumber dari al-Quran,

${ }^{31}$ Lia Rofiani, "Strategi Pemasaran Produk Pembiayaan Gadai Emas Di Bank Syariah Mandiri Cabang Pembantu Gubug” (IAIN Salatiga, 2015), 2 . 
Sunnah dan ijma'. Di Indonesia terdapat fatwa DSN MUI yang menjelaskan kebolehan hukum gadai.

Adanya dasar yang membolehkan sesuatu tentunya berimplikasi pada unsur-unsur kemaslahatan yang terkandung di dalamnya. Salah satunya dengan gadai ini, ia diperbolehkan karena memiliki tujuan untuk membantu seseorang yang sedang mengalami kesulitan dalam aktifitas kesehariannya. Gadai (ar-Rahn) sendiri memiliki rukun dan syarat tertentu yang harus terpenuhi agar gadai dapat dilaksanakan berdasarkan kebaikan dan kemaslahatan bagi kedua belah pihak yang melaksanakan transaksi tersebut. Jika rukun dan syarat gadai tidak terpenuhi atau melanggar ketentuan syarat dalam Islam dan unsur kemaslahatan maka hukumnya dinyatakan batal.

\section{Daftar Pustaka}

Ali, Abu Ibrahim Muhammad. "Hukum Gadai Dalam Al-Qur'an Dan Al-Hadits." Syifa-Alqulub.Blogspot.Com, 2012. http://syifa-alqulub.blogspot.com/2012/04/hukumgadai-dalam-al-quran-dan-hadist.html.

Amir, Rahma. "Gadai Tanah Perspektif Ekonomi Islam." Jurnal Muamalah 5, no. 1 (2015).

Antonio, Muhammad Syafii. Bank Syariah: Dari Teori Ke Praktik. Jakarta: Gemma Insani, 2001.

Arif, Mahmud. "Islam, Kearifan Lokal Dan Kontekstualisasi

Pendidikan: Kelenturan, Signifikansi, Dan Implikasi Edukatifnya." Al-Tahrir: Jurnal Pemikiran Islam 15, no. 1 (2015).

"Buku II Bab 20 Pasal 1150 Sampai Dengan Pasal 1161 KUHPerdata," n.d.

Cahyani, Yutisa Tri. "Konsep Fee Based Services Dalam Perbankan Syariah." El Barka: Journal of Islamic Economics and Business 1, no. 2 (2018).

Devita, Irma. "Jenis-Jenis Gadai," 2012. http://irmadevita.com/tag/gadai.

Effendy, Hari. "Perlindungan Hukum Kepada Kreditur 
Pemegang Gadai Dan Pihak Ke III Dalam Perjanjian Gadai Terhadap Barang Jaminan Di Perum Pegadaian Kota Semarang." Universitas Diponegoro, 2008.

Febriani, Dwi. "Konsep Gadai Dan Pemanfaatan Barang Gadai Menurut Sayyid Sabiq." Universitas Islam Negeri Sultan Syarif Kasim Riau, 2011.

"HR. Bukhari 2737, Muslim 1632, Tirmidzi 1375," n.d. "HR Bukhari No. 1926, Kitab Al-Buyu, Dan Muslim," n.d. "Hukum Gadai Syariah." Taukhid.Wordpress.Com, 2012. http://taukhid.wordpress.com/2012/05/22/hukumgadai-syariah/.

Ichsan, Nurul. "Akad Bank Syariah." Asy-Syir'ah: Jurnal Ilmu Syari'ah Dan Hukum 50, no. 2 (2016).

Jahja, Adi Susilo. "Analisis Perbandingan Kinerja Keuangan Perbankan Syariah Dengan Perbankan Konvensional." Epistemé: Jurnal Pengembangan Ilmu Keislaman 7, no. 2 (2012).

Kamil, Ahmad, and M. Fauzan. Kitab Undang-Undang Hukum Perbankan Dan Ekonomi Syariah. Jakarta: Prenada Media, 2007.

Kitab Undang-Undang Hukum Perdata. Rhedbook Publisher, 2008.

Mait, Tokichi K. "Tinjauan Yuridis Terhadap Eksekusi Gadai Dan Perlindungan Hukum Menurut Hukum Positif Di Indonesia." Lex Et Societatis 7, no. 9 (n.d.).

"Manajemen Pegadaian Konvensional vs Syariah," n.d. http://www.scribd.com/doc/6429241/Manajemen-

Pegadaian-Konvensional-vs-Syariah pada tanggal 21 Juni 2012.

Masmuah, and Sukresno. "Tinjauan Yuridis Implementasi Gadai Syariah Pada Kantor Bank BRI Syariah Kudus." Jurnal Sosial Dan Budaya 6, no. 1 (2013).

Moningka, Gabriel. "Hak PT. Pegadaian Melaksanakan Pelelangan Barang Emas." Lex Privatum 1, no. 2 (2013).

Novia, Yandi. "Hak Gadai." Palangkaraya: Universitas Muhammadiyah Palangkaraya, 2014.

Oktavianto, Joni, R. Suharto, and Triyono. “Anggung Jawab PT. 
Pegadaian (Persero) Atas Kerusakan Dan Kehilangan Barang Gadai Di PT. Pegadaian (Persero) Kota Semarang." Diponegoro Law Journal 5, no. 3 (2016).

Rofiani, Lia. "Strategi Pemasaran Produk Pembiayaan Gadai Emas Di Bank Syariah Mandiri Cabang Pembantu Gubug." IAIN Salatiga, 2015.

Rofiani, Novi. "Perilaku Nasabah Dalam Memilih Produk Pembiayaan Pegadaian Pada PT. Bank Syari'ah Mandiri TBK." Al-Iqtishad 1, no. 2 (2009).

Sudjana, Adang. "Bank Syariah Sebagai Alternatif." The Winners 4, no. 1 (2003): 46-53.

Susilowati, Tri Pudji. "Pelaksanaan Gadai Dengan Sistem Syariah Di Perum Pegadaian Semarang." Universitas Diponegoro, 2008.

Syafe'i, Rachmat. Fiqih Muamalah. Bandung: Pustaka Setia, 2001.

Syafuri, H. B. "Aktivitas Gadai Syariah Dan Implikasinya Terhadap Produktivitas Masyarakat Di Provinsi Banten." Al-Adalah 12, no. 2 (2014). 